\title{
ASSOCIATION BETWEEN CHRONIC OBSTRUCTIVE PULMONARY DISEASE AND MORTALITY CAUSED BY COVID-19: A META-ANALYSIS
}

\author{
Pamogsa Daniyar1), Agus Kristiyanto², Setyo Rahardjo3) \\ ${ }^{1)}$ Masters Program in Public Health, Universitas Sebelas Maret \\ ${ }^{2)}$ Faculty of Sport, Universitas Sebelas Maret \\ 3)Faculty of Medicine, Universitas Sebelas Maret
}

\begin{abstract}
Background: Recent studies showed that patients with chronic respiratory diseases, particularly chronic obstructive pulmonary disease (COPD), have a high risk for COVID-19 infection due to their poor underlying lung reserve and increased expression of angiotensin-converting enzyme 2 (ACE-2) receptor in the small airways. A systematic review and meta-analysis was conducted to investigate association between chronic obstructive pulmonary disease and mortality caused by COVID-19.

Subjects and Method: This was a systematic review and meta-analysis was conducted by PRISMA flow diagram. The articles were collected from PubMed, Google Scholar, Science Direct, BMJ, Garuda, SINTA, and national library databases. Keywords used "Anxiety" AND "Nurses" AND "COVID-19". Article search is carried out by considering the eligibility criteria, including population= COVID-19 patients, intervention $=$ chronic obstructive pulmonary disease, comparison $=$ without comorbid disease, and outcome $=$ mortality. The inclusion criteria were full text, articles were published from year 2020 to 2021, cohort studies, used English language, and reported adjusted Odds Ratio. Articles that met the criteria were analyzed by Revman 5.3.

Results: A meta analysis study including 9 studies showed that chronic obstructive pulmonary disease increased mortality risk in COVID-19 patients $(\mathrm{aOR}=1.51 ; 95 \% \mathrm{CI}=$ 1.21 to $1.9 ; \mathrm{p}<0.001)$.

Conclusion: chronic obstructive pulmonary disease increases mortality risk in COVID-19 patients.
\end{abstract}

Keywords: chronic obstructive pulmonary disease, COVID-19, mortality

\section{Correspondence:}

Pamogsa Daniyar. Masters Program in Public Health, Universitas Sebelas Maret. Jl. Ir. Sutami 36A, Surakarta 57126, Central Java. Email: pamogsadaniyar@gmail.com. Mobile: +6285290601552 . 